\title{
Contributions of local and regional sources to fine PM in the megacity of Paris
}

\author{
K. Skyllakou ${ }^{1,2}$, B. N. Murphy ${ }^{3}$, A. G. Megaritis ${ }^{1,2}$, C. Fountoukis ${ }^{2}$, and S. N. Pandis ${ }^{1,2,4}$ \\ ${ }^{1}$ Department of Chemical Engineering, University of Patras, Patras, Greece \\ ${ }^{2}$ Institute of Chemical Engineering Sciences, Foundation for Research and Technology Hellas (FORTH/ICE-HT), \\ Patras, Greece \\ ${ }^{3}$ Department of Meteorology \& Department of Applied Environmental Science, Stockholm University, Stockholm, Sweden \\ ${ }^{4}$ Department of Chemical Engineering, Carnegie Mellon University, Pittsburgh, PA 15213, USA
}

Correspondence to: S. N. Pandis (spyros@ chemeng.upatras.gr)

Received: 30 July 2013 - Published in Atmos. Chem. Phys. Discuss.: 8 October 2013

Revised: 11 January 2014 - Accepted: 21 January 2014 - Published: 6 March 2014

\begin{abstract}
The particulate matter source apportionment technology (PSAT) is used together with PMCAMx, a regional chemical transport model, to estimate how local emissions and pollutant transport affect primary and secondary particulate matter mass concentration levels in Paris. During the summer and the winter periods examined, only $13 \%$ of the $\mathrm{PM}_{2.5}$ is predicted to be due to local Paris emissions, with $36 \%$ coming from mid-range $(50-500 \mathrm{~km}$ from the center of the Paris) sources and $51 \%$ from long range transport (more than $500 \mathrm{~km}$ from Paris).

The local emissions contribution to simulated elemental carbon (EC) is significant, with almost $60 \%$ of the EC originating from local sources during both summer and winter. Approximately $50 \%$ of the simulated fresh primary organic aerosol (POA) originated from local sources and another $45 \%$ from areas $100-500 \mathrm{~km}$ from the receptor region during summer. Regional sources dominated the secondary PM components. During summer more than $70 \%$ of the simulated sulfate originated from $\mathrm{SO}_{2}$ emitted more than $500 \mathrm{~km}$ away from the center of the Paris. Also more than $45 \%$ of secondary organic aerosol (SOA) was due to the oxidation of VOC precursors that were emitted $100-500 \mathrm{~km}$ from the center of the Paris. The model simulates more contribution from long range secondary PM sources during winter because the timescale for its production is longer due to the slower photochemical activity.

PSAT results for contributions of local and regional sources were compared with observation-based estimates from field campaigns that took place during the MEGAPOLI
\end{abstract}

project. PSAT simulations are in general consistent (within $20 \%$ ) with these estimates for OA and sulfate. The only exception is that PSAT simulates higher local EC contribution during the summer compared to that estimated from observations.

\section{Introduction}

Fine particles $\left(\mathrm{PM}_{2.5}\right)$ can cause a variety of problems to human health including premature death (Dockery et al., 1993; Kunzli et al., 2000; Klemm et al., 2000; Pope et al., 2002). $\mathrm{PM}_{2.5}$ is also responsible for visibility reduction (Seinfeld and Pandis, 2006) and contributes to acid rain formation (Burtraw et al., 2007) and climate change by affecting the energy balance of our planet (Schwartz, 1996).

One of the main challenges when trying to improve air quality in large urban areas is the quantification of the contributions of local as well as long range pollutant transport. Identifying the areas affecting the receptor is also a crucial issue.

A number of approaches have been proposed and used in order to estimate the role of local and regional sources in different areas. Three-dimensional chemical transport models (CTMs) can simulate all relevant atmospheric processes, so they have been used in several different approaches. The simplest method is the so called "zero-out analysis" or "bruteforce method" (Park et al., 2003; Knipping et al., 2006; Chin et al., 2007; Koo et al., 2009) which requires running the 
corresponding CTM multiple times by zeroing out the emissions of a specific source area or type. This is a computationally expensive method because it requires multiple simulations, one for each source area of interest. Another approach is the direct decoupled method (DDM) (Dunker et al., 1981) which can provide local derivatives of the simulated pollutant levels to model parameters (such as emissions or process rate constants). DDM has been used to calculate the sensitivity of the concentration levels to changes in emissions. In general, DDM cannot be applied in large-scale perturbations (Dunker et al., 2002). To overcome these problems, Ying and Kleeman (2006) developed the source-oriented external mixture (SOEM) approach introducing additional species for each source and tracking them separately throughout the model. In SOEM each secondary PM species is traced back to its precursors. For example the concentration of particulate sulfate is traced back to $\mathrm{SO}_{2}$ sources. Ying and Kleeman (2009) used SOEM to quantify transport distances in areas of California. SOEM is accurate but computationally demanding. Wagstrom et al. (2008) developed a computational efficient apportionment algorithm, the particulate source apportionment technology (PSAT) and used it for the first time in the Eastern United States (Wagstrom and Pandis, 2011a) to estimate the contributions of emissions as a function of distance from the receptor for several urban and rural sites. PSAT is computationally efficient as it works in parallel with the main CTM without interfering with the CTM's calculations. Koo et al. (2009) used PSAT to analyze concentrations from different source regions and compared them with the brute force method's results. They showed that DDM and PSAT can give similar results for pollutants that are related linearly with emissions but otherwise the results differ because of the nonlinearity of the chemistry of secondary species or other indirect effects.

In this study we will focus on the megacity of Paris. Air quality of Paris has been investigated through different models such as CHIMERE (Zhang et al., 2013), PMCAMx (Fountoukis et al., 2013), POLYPHEMUS (Royer et al., 2011), and $\mathrm{H}^{2} \mathrm{O}$ (Couvidat el al., 2013). Sciare et al. (2010) compared SOA predictions of the regional CTM, CHIMERE using a single step oxidation SOA scheme (Pun et al., 2006) against observation-based estimates from the "EC-tracer" method (Turpin and Huntzicker, 1995; Strader et al., 1999; Cabada et al., 2004) at an urban site. Fountoukis et al. (2013) applied a fine grid nest over the megacity of Paris with high resolution $\left(4 \times 4 \mathrm{~km}^{2}\right)$. The evaluation of the model against high time-resolution (AMS) measurements of fine particulate matter from three sites was encouraging. Zhang et al. (2013) implemented the VBS approach into CHIMERE to simulate the behavior of organic aerosol and compared with measurements performed during the MEGAPOLI summer campaign (Baklanov et al., 2010).

Beekmann et al. (2014) used measurements inside the center of the Paris and the surrounding areas to estimate what fraction of the particulate matter is local. The data were col- lected, during July 2009 and January to mid-February 2010 as a part of the MEGAPOLI intensive field campaigns (Beekmann et al., 2014). $\mathrm{PM}_{1}$ concentration in Paris during summer was on average between 5.3 and $7.5 \mu \mathrm{g} \mathrm{m}^{-3}$, but during winter was between $15.2 \mu \mathrm{g} \mathrm{m}^{-3}$ and $18.5 \mu \mathrm{g} \mathrm{m}^{-3}$. The same authors also estimated, based on the measurements in the appropriate upwind site, that more than $70 \%$ of $\mathrm{PM}_{2.5}$ was transported into Paris from areas far away from it. During more polluted periods $\left(\mathrm{PM}_{2.5}>40 \mu \mathrm{g} \mathrm{m}{ }^{-3}\right.$ at the urban site), the regional contribution was even larger (on average $80 \%$ ). In all, $70 \%$ of the OA was found to be transported from regional sources during both summer and winter. Freutel et al. (2013) found that the concentrations of secondary species such as oxygenated OA, nitrate and ammonium during the summer MEGAPOLI campaign were quite similar for the three measurement sites in Paris, indicating the dominance of regional transport. Significant levels of secondary species were transported to Paris when the corresponding air masses originated from continental Europe. The importance of the regional sources in Paris was also confirmed by Crippa et al. (2013) for the winter MEGAPOLI period.

The MEGAPOLI measurements provide a unique opportunity to compare the PSAT simulations with the estimated regional contributions. In addition, PSAT can quantify the average transport distance from regional sources to the Paris area, thus providing additional insights. The original version of PSAT has been based on PMCAMx-2002, a CTM that assumes that primary OA is non-volatile and inert and simulated SOA formation using the Odum et al. (1996) 2-product approach. Recent developments including the semi-volatile POA and the continuous aging of OA (Robinson et al., 2007; Lane et al., 2008; Shrivastava et al., 2008) have not been considered in previous source-receptor analyses by PSAT or other algorithms.

In this work we first extend PSAT so that it can work with the VBS approach (Donahue et al., 2006) for OA. We then apply the extended PSAT in PMCAMx-2008 in the European domain focusing on Paris for the first time. This paper describes the PSAT application to the megacity of Paris for two different seasons corresponding to the MEGAPOLI intensive campaigns.

\section{Model description}

\subsection{PMCAMx-2008}

The model used in this study is PMCAMx-2008 (Fountoukis et al., 2011), a regional three-dimensional CTM. PMCAMx-2008 is applied to Europe, covering a region of $5400 \times 5832 \mathrm{~km}^{2}$, using $36 \mathrm{~km} \times 36 \mathrm{~km}$ grid resolution and 10 vertical layers extending up to $6 \mathrm{~km}$. The model is applied for two periods, 1-30 July 2009 and 10 January-9 February 2010 . The gas-phase chemical mechanism used is based on the SAPRC99 mechanism, including 211 reactions of 56 
gases and 18 radicals. The PMCAMx SAPRC99 version uses five lumped alkanes, two olefins, two aromatics, isoprene, a lumped monoterpene species, and a lumped sesquiterpene species. OA is treated in this work as in Murphy and Pandis (2010). Fountoukis et al. (2011) evaluated the PMCAMx2008 performance for the same European domain against ground measurements taken at four measurement stations and airborne measurements during May 2008. The model reproduced more than $87 \%$ of the hourly measurements of $\mathrm{PM}_{1} \mathrm{OA}$ and more than $94 \%$ of the daily averaged OA concentrations within a factor of 2 . Fountoukis et al. (2013) investigated the role of grid nesting for air quality simulations in Paris, by comparing the results of PMCAMx-2008 with $4 \mathrm{~km} \times 4 \mathrm{~km}$ grid resolution to those of lower resolution (of $36 \mathrm{~km} \times 36 \mathrm{~km}$ ) for the summer and winter period of the MEGAPOLI campaign. Fountoukis et al. (2013) also evaluated the model against ground based measurements at the three MEGAPOLI sites of Paris. For the site located in the center of the Paris (LHVP) the average simulated sulfate during summer was within $0.2 \mu \mathrm{g} \mathrm{m}^{-3}$ of the measured value and the simulated EC was within $0.5 \mu \mathrm{g} \mathrm{m}^{-3}$. For the suburbs of Paris (SIRTA site) during summer, the model simulations were also in agreement with measurements of sulfate and OA components. EC was simulated to be lower than the measured concentration, by less than $0.2 \mu \mathrm{g} \mathrm{m}^{-3}$.

\subsection{PSAT description}

The particulate source apportionment technology (PSAT) (Wagstrom et al., 2008) is an apportionment algorithm that can track different pollutant categories originating from different area sources or different source types. It is computationally efficient as it works in parallel with the main CTM without increasing the CTM's computational time. PMCAMx-2008 communicates with the apportionment algorithm after each step of each process (e.g., gas phase chemistry, horizontal and vertical advection, etc.) by sending the corresponding concentrations of each species calculated by the CTM's modules to the apportionment algorithm. After each process step of the main CTM, PSAT calculates the apportionment for each source and for each species. The initial conditions of the code are considered as a separate "source" but their effect decays rapidly during the simulation and becomes negligible after a few days. The PSAT code requires a source-resolved inventory and matches the corresponding emissions with the corresponding sources. PSAT uses the apportionment of the upwind grid cell to apportion species after transport calculations instead of tracking the source-specific species separately. Equation (1) (Wagstrom et al., 2008) describes the apportionment of the newly formed species A in a specific grid cell $i$ :

$c_{\mathrm{A}, i}(t+\Delta t)=c_{\mathrm{A}, i}(t)+\Delta c_{\mathrm{in}}\left[\frac{c_{\mathrm{A}, i}^{*}(t)}{c_{\mathrm{A}}^{* T}(t)}\right]-\Delta c_{\mathrm{out}}\left[\frac{c_{\mathrm{A}, i}(t)}{c_{\mathrm{A}}^{T}(t)}\right]$, where $c_{\mathrm{A}, i}(t)$ is the concentration of species A from source $i$ in a specific cell at the beginning of the corresponding time step and $c_{\mathrm{A}, i}(t+\Delta t)$ is the same quantity at the end of the time step, $\Delta c_{\text {in }}$ is the concentration transported into the grid cell, $\Delta c_{\text {out }}$ is the concentration transported out of the grid cell, $c_{\mathrm{A}, i}^{*}$ is the concentration of species A from source $i$ in the upwind grid cell and $c_{\mathrm{A}, i}^{* T}$ is the total concentration of species A from all sources in the upwind grid cell. The apportionment of the newly formed secondary PM is calculated based on the apportionment of its precursor species. This means that the apportionment of each secondary PM species is calculated by the same equations as the apportionment of its gas phase precursor.

We have extended the original PSAT algorithm of Wagstrom et al. (2008) to describe the OA mass based on the VBS approach (Donahue et al., 2006; Stanier et al., 2008). Primary OA emissions are distributed into different classes of saturation concentrations (volatility bins). The corresponding gas-phase POA compounds can be oxidized by the hydroxyl radical leading to products of lower volatility. In the same way, SOA is considered to be semi-volatile and can also be oxidized further in the gas phase forming lower volatility products. PSAT keeps track of the sources of all OA components (fresh primary, oxidized primary, fresh and aged anthropogenic and biogenic secondary) using the same approach used for all semi-volatile species. All OA species are distributed into different volatility bins and are tracked by PSAT as separate species. OA species are distributed between the gas and the particle phase according to Eq. (2) (Donahue et al., 2006):

$\xi_{i}=\left(1+\frac{C_{i}^{*}}{C_{\mathrm{OA}}}\right)^{-1}$

where $\xi_{i}$ is the partitioning coefficient of compound $i$ (fraction of compound in the particulate phase), $C_{i}^{*}$ its effective saturation concentration and $C_{\mathrm{OA}}$ is the total organic mass concentration. Each $C_{i}^{*}$ corresponds to a different volatility bin in the volatility basis set. Chemical aging reactions are assumed to shift the organic mass to the next lower volatility bin corresponding to a reduction of the volatility by one order of magnitude.

The apportionment of all semi-volatile secondary organic species is treated as a reversible process and the apportionment of the newly formed OA, regardless of its volatility, is based on the apportionment of its gas-phase VOC precursor.

\subsection{Definition of source regions within and around the Paris metropolitan area}

We have chosen nine computational cells to describe the Paris metropolitan area. We have also defined areas covering distances of approximately $50 \mathrm{~km}, 500 \mathrm{~km}$, and greater than $500 \mathrm{~km}$ away from the center of the Paris metropolitan area (Fig. 1) for the calculation of the corresponding source contributions to PM levels. 


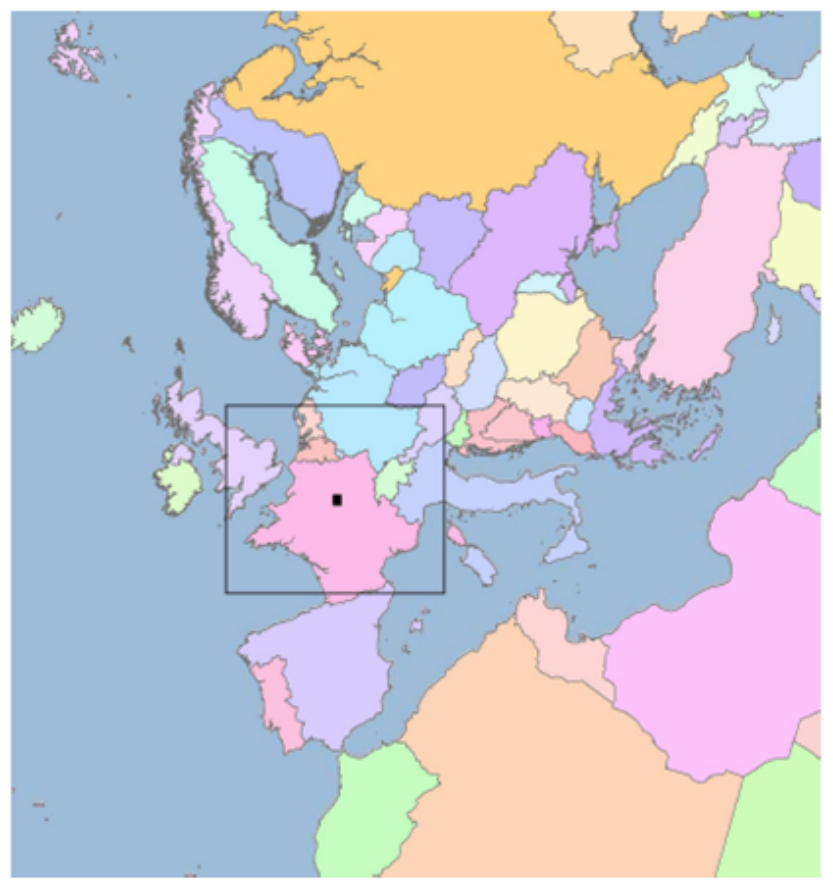

Fig. 1. Definition of different source areas around Paris indicating local Paris emissions (black filled area), $500 \mathrm{~km}$ from the center of Paris (area inside the black box not including Paris) and $>500 \mathrm{~km}$ (area outside the black box).

PSAT also tracks the contributions to particle concentrations from initial conditions and boundary conditions. Concentrations resulting from emissions within Paris are considered as local. The sum of the concentrations resulting from emissions outside the Paris metropolitan area but within $500 \mathrm{~km}$ from the center of Paris is considered as contribution of mid-range transport and those resulting from emissions more than $500 \mathrm{~km}$ away from Paris (including the effects of boundary conditions) are considered as long range transport. The long range contribution therefore includes also the emissions outside of the modeling domain.

\section{Quantification of source area contributions}

\subsection{Summer}

We will focus first on mass concentration of three representative major PM species: elemental carbon, sulfate, and secondary organic aerosol. Elemental carbon is a non-reactive primary species, sulfate is secondary non-volatile, and SOA is a secondary semi-volatile species.

Figure 2 depicts the simulated diurnal pattern of EC, fresh POA, sulfate and SOA and the corresponding source areas. The EC concentration peaks at 08:00 LT in the morning. The concentration of elemental carbon is on average $1 \mu \mathrm{g} \mathrm{m}^{-3}$. During the hours of the day with the high concentrations the contribution of local transport is higher. The contribution of
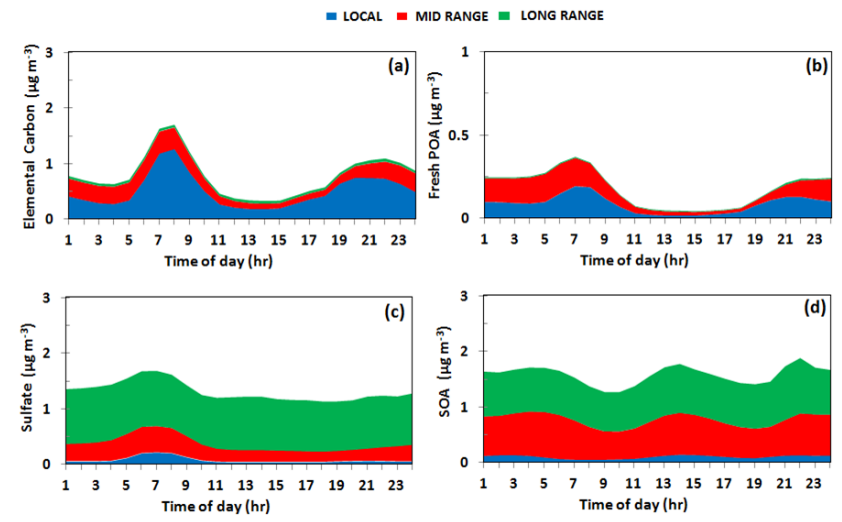

Fig. 2. Average simulated diurnal profiles of $\mathrm{PM}_{2.5}$ components and their sources for the summer period for: (a) elemental carbon; (b) fresh POA; (c) sulfate and (d) SOA.

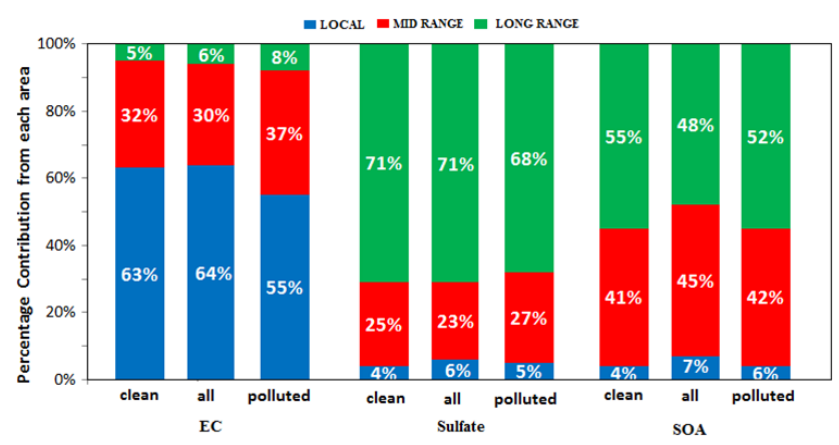

Fig. 3. Percent contributions from each area during high, all, and low particulate matter concentration days for the simulated summer period.

local sources for EC is on average $64 \%$ while the contributions of mid- and long range transport are $30 \%$ and $6 \%$ respectively (Fig. 3). This behavior is characteristic of primary pollutants with significant urban sources (Wagstrom and Pandis, 2011b).

POA has almost the same behavior as EC with a morning peak at 07:00 LT in the morning, but with lower concentration level than EC (on average less than $0.5 \mu \mathrm{g} \mathrm{m}^{-3}$ ).

The behavior of sulfate is quite different because it is a secondary species. Average contributions of local, mid-range transport and long range transport to sulfate in Paris are $6 \%, 23 \%$ and $71 \%$, respectively (Fig. 3). This indicates that sulfate in Paris is mainly originating from areas more than $500 \mathrm{~km}$ away from the city. This is the result of the time required for its formation and the location of the major $\mathrm{SO}_{2}$ sources.

Similarly to sulfate, less than $10 \%$ of the SOA in Paris is simulated to be the result of local sources. SOA consists of all the secondary compounds formed from reactions of evaporated POA, intermediate volatility organic compounds (IVOCs), and VOCs. SOA also includes the contribution of the boundary conditions for OA. Paris has modest VOC 


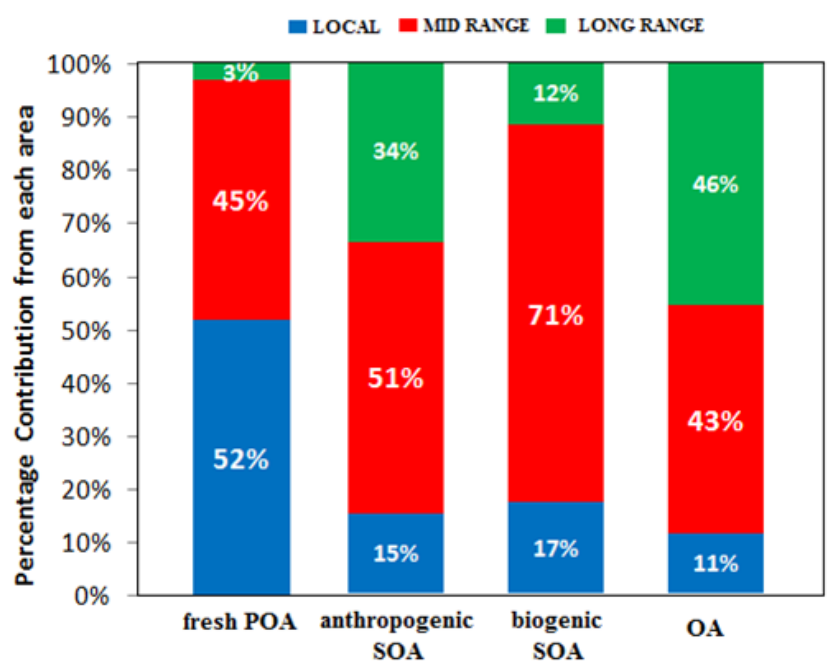

Fig. 4. Percent contributions from each transport category (local, mid-range and long-range) for different types of organic aerosol during the summer. Long range $\mathrm{OA}$ also includes the transported $\mathrm{OA}$ into the domain.

emissions compared to its surroundings and also several hours are required for the formation of SOA from freshly emitted VOCs. At the same time VOC emissions originating from Paris can be transported to other areas away from the city and can be oxidized there, forming semi-volatile oxidation products which can condense to form SOA. Mid- and long range sources dominate contributing $45 \%$ and $48 \%$ respectively of the SOA levels in the center of Paris.

Figure 3 summarizes the average simulated contribution from each source during clean and polluted days. Clean days are defined as the days with average concentrations of total $\mathrm{PM}_{2.5}$ mass concentration in the lower quartile of the values analyzed during this period. Polluted days are defined as the days with average total $\mathrm{PM}_{2.5}$ concentrations in the upper quartile. During more polluted days $55 \%$ of the EC is emitted by local sources with another $37 \%$ coming from mid-range sources. On the other hand, during clean days these contributions of EC are on average $63 \%$ and $32 \%$, respectively. The contributions of different sources for sulfate and SOA do not change very much during cleaner days compared to those of polluted days. It is noteworthy that PMCAMx/PSAT simulates that the relative contribution of sources in Paris to total $\mathrm{PM}_{2.5}$ tends to be lower during polluted than during average days. This rather surprising result is consistent with the observation-based estimates of Beekmann et al. (2014).

\subsubsection{Organic aerosol sources}

A little more than $50 \%$ of fresh POA in Paris is simulated to be the result of emissions from local sources according to PSAT, while another $45 \%$ is due to mid-range transport and less than $5 \%$ comes from areas more than $500 \mathrm{~km}$ away

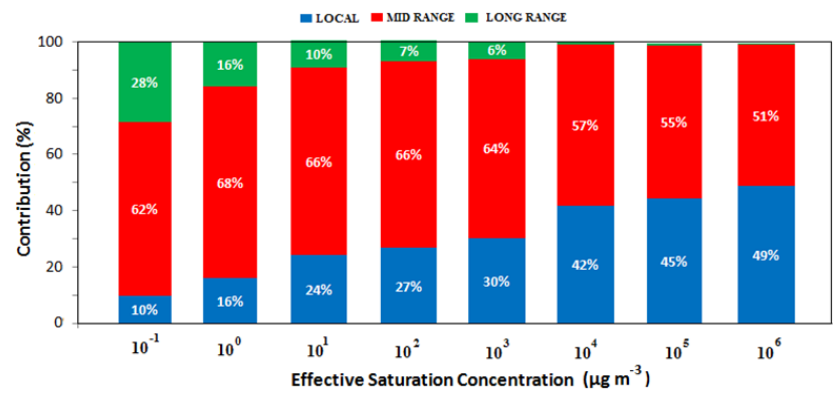

Fig. 5. Simulated source area contributions to organics (organic aerosol plus gas-phase organic mass) in Paris as a function of their volatility. Compounds with effective saturation concentrations above $10 \mu \mathrm{g} \mathrm{m}^{-3}$ are mainly in the gas phase, while the rest are partitioned between the gas and particulate phases.

(Fig. 4). The POA contributions are similar to those of the $\mathrm{EC}$, but with a lower local contribution due to the evaporation of POA after emission.

Secondary organic aerosol precursors emitted far from Paris are oxidized to form SOA which is then transported to the megacity. Almost $50 \%$ of anthropogenic SOA in Paris is simulated to be due to mid-range transport and another $34 \%$ due to long range transport. The behavior of biogenic SOA is quite similar with outside sources contributing on average $83 \%$ (Fig. 4). Total organic aerosol behaves like SOA with local emissions contributing on average $11 \%$, mid-range transport $43 \%$ and long range $46 \%$ (Fig. 4). Long range transport dominates for total OA because the boundary conditions contribute on average $30 \%$ during the summer.

As the volatility of organics increases, the contribution of local sources is simulated to increase (Fig. 5). Organics originating from local sources are in general less oxidized with higher volatilities, but organics which originate from long distances are heavily oxidized and typically of lower volatility. For the least volatile OA components in PMCAMx (effective saturation of $10^{-1} \mu \mathrm{g} \mathrm{m}^{-3}$ ), the contribution of local sources is simulated to be on average $10 \%$ and the contribution of mid- and long range transport is $62 \%$ and $28 \%$ respectively. On the other hand for the more volatile OA components (effective saturation of $10^{4} \mu \mathrm{g} \mathrm{m}^{-3}$ ), the contribution of local sources is $42 \%$ and the contribution of mid-range transport is on average $57 \%$. These high volatility compounds are mostly in the gas phase.

\subsubsection{Effects of Paris on other areas}

PSAT has the ability to estimate the impacts of a specific source area, Paris in this application, on other areas and also the impacts of the other specified areas on the receptor region. In order to quantify how far from Paris the plume of each species can travel, we can use a variety of metrics (Wagstrom et al., 2011a). The transport distance (TD) is a useful metric of the average transport distance. TD has been 


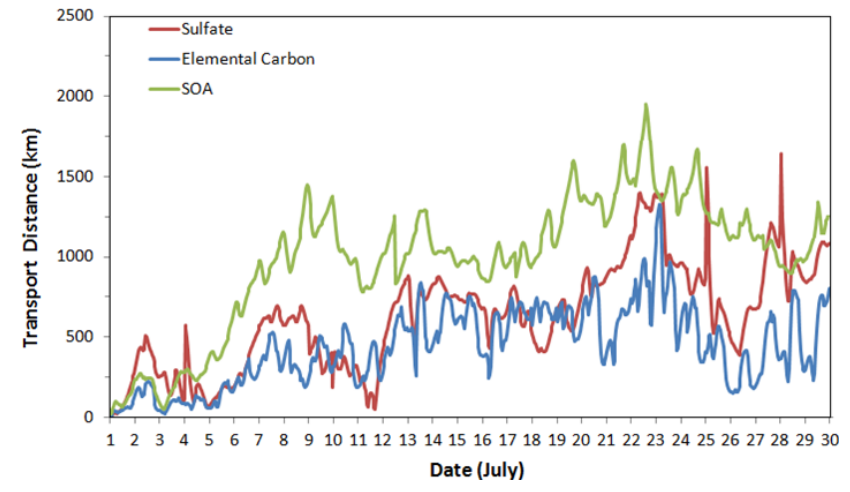

Fig. 6. Temporal variation of the transport distance for EC, sulfate and SOA at ground level for Paris emissions for the simulated summer period.

defined by Wagstrom et al. (2011b) as the distance between the center of emissions and the center of the plume of the simulated concentrations at a given time. The coordinates of the centers $\left(X_{c, n}, Y_{c, n}\right),\left(X_{e, n}, Y_{e, n}\right)$ are calculated based on Eqs. (3) and (4) (Wagstrom et al., 2011a):

$$
\begin{aligned}
& \left(X_{c, n}, Y_{c, n}\right)=\left(\frac{\sum_{i} X_{i} c_{i, n}}{\sum_{i} c_{i, n}}, \frac{\sum_{i} Y_{i} c_{i, n}}{\sum_{i} c_{i, n}}\right) \\
& \left(X_{e, n}, Y_{e, n}\right)=\left(\frac{\sum_{i} X_{i} e_{i, n}}{\sum_{i} e_{i, n}}, \frac{\sum_{i} Y_{i} e_{i, n}}{\sum_{i} e_{i, n}}\right),
\end{aligned}
$$

where $c_{i, n}$ are the concentrations, $e_{i, n}$ are the corresponding emissions of cell $i, n$ is the corresponding source area and $X_{i}, Y_{i}$ are the coordinates of the cells of the corresponding concentrations and the emissions. For the calculation of the TD of secondary species like sulfate and SOA, the coordinates of the emission centers are calculated based on the emissions of their precursor gases, $\mathrm{SO}_{2}$ and VOCs, respectively. Figure 6 shows the temporal variation of the simulated TD (from precursors emitted from the center of the Paris) during the simulated summer period, for EC, sulfate and SOA. The TD is quite variable because it depends strongly on meteorology. EC travels on average $400 \mathrm{~km}$ from Paris and this TD is simulated to be lower than that of sulfate $(600 \mathrm{~km})$ and SOA $(800 \mathrm{~km})$. Figure 7 shows the average impacts of local Paris emissions of EC, $\mathrm{SO}_{2}$ and VOCs on PM in areas far from Paris. Even if the plumes extend hundreds of kilometers away from Paris, the absolute effects of this megacity are modest (less than $0.1 \mu \mathrm{g} \mathrm{m}^{-3}$ for each $\mathrm{PM}_{2.5}$ component) due to the relatively low emissions of the urban region.

\subsection{Winter}

The relative source contributions during winter are quite similar to those during summer, despite the differences in absolute concentration levels. Winter is generally characterized

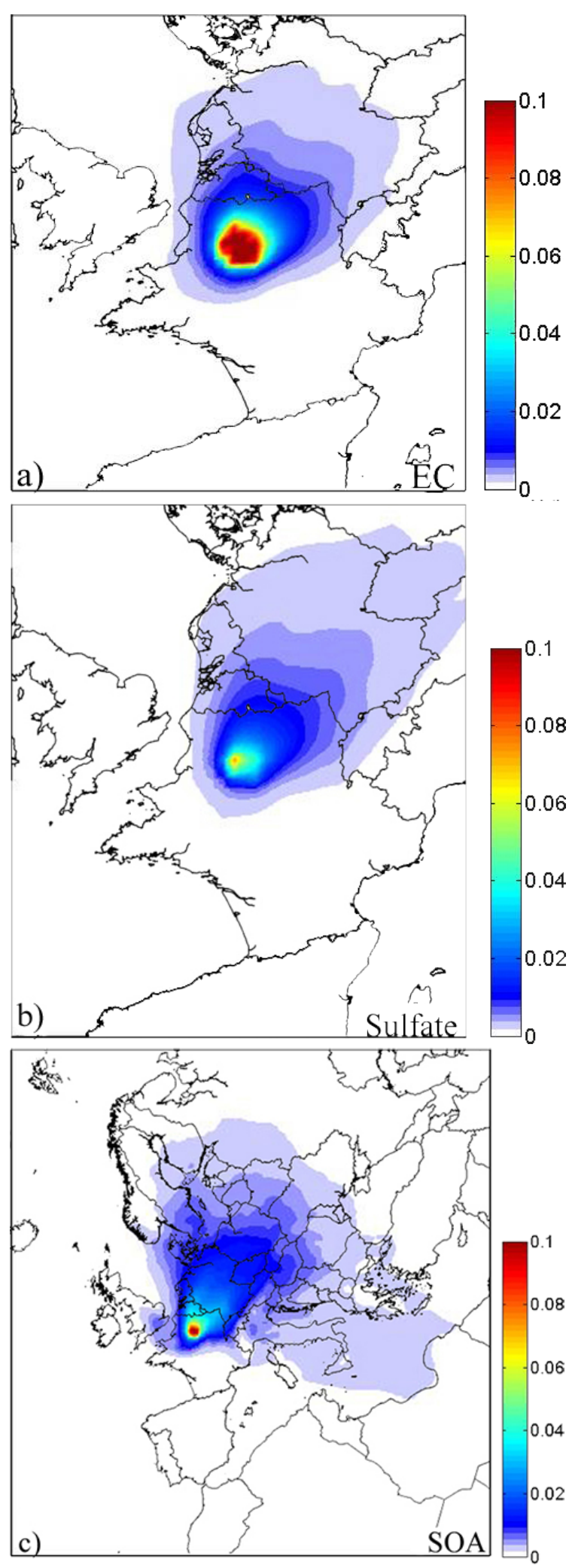

Fig. 7. Simulated average ground concentrations (in $\mu \mathrm{g} \mathrm{m}^{-3}$ ) of $\mathrm{PM}_{2.5}$ : (a) EC, (b) sulfate and (c) SOA originating from the Paris area. 
- LOCAL = MID RANGE $=$ LONG RANGE
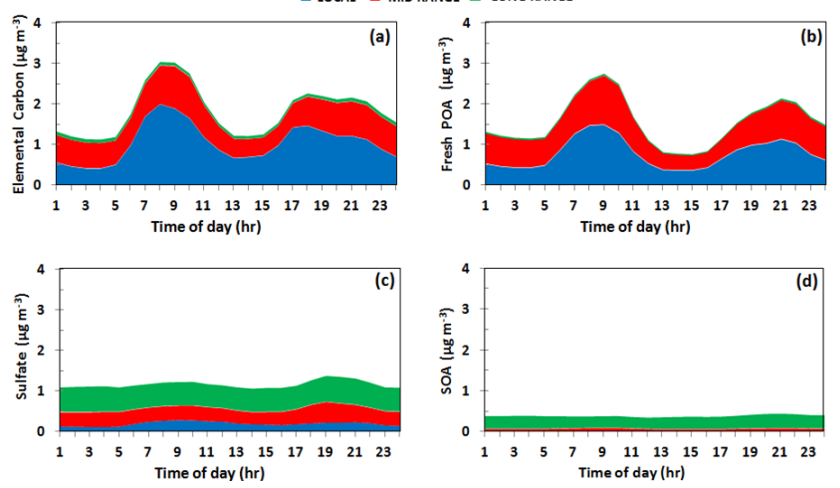

Fig. 8. Average diurnal profiles of $\mathrm{PM}_{2.5}$ components and corresponding source areas for the winter period simulated for: (a) elemental carbon, (b) fresh POA, (c) sulfate, and (d) SOA.

by higher emissions of EC and fresh POA and lower emissions of biogenic SOA precursors compared to summer (Table 1). During winter the average simulated concentration of EC in Paris was $2 \mu \mathrm{g} \mathrm{m}^{-3}$, while during summer it was $1 \mu \mathrm{g} \mathrm{m}^{-3}$. Also the difference in concentrations between the two periods for fresh POA is significant. The simulated POA during winter is $1.5 \mu \mathrm{g} \mathrm{m}^{-3}$ and during summer $0.2 \mu \mathrm{g} \mathrm{m}^{-3}$. The simulated diurnal patterns of the concentrations and the corresponding source areas of EC, sulfate, fresh POA and SOA are shown in Fig. 8. The diurnal average profiles of EC and fresh POA are quite similar, with a morning peak and reveal that during the hours with the maximum concentration levels, the contribution of local emissions is higher. During winter the concentrations of secondary species such as sulfate and SOA are lower compared to summer because of the slower photochemistry. The diurnal profile of sulfate is almost flat showing again that local emissions do not play an important role.

The seasonal changes in emissions, contribute to the differences in relative source contributions. These seasonal changes are summarized in Table 1. However, this effect is only part of the story as changes in transport patterns, residence time of local emissions over Paris, removal, photochemistry, etc., also affect the relative contributions of the different areas.

EC during winter is characterized by a little lower local Paris contributions and a little higher transport from midrange sources compared to summer (Fig. 9). The contribution of long range transport for sulfate is lower during winter due to lower regional sulfate levels. During winter the contributions of long range transport are lower, because PM components cannot travel long distances as they are removed by rain.

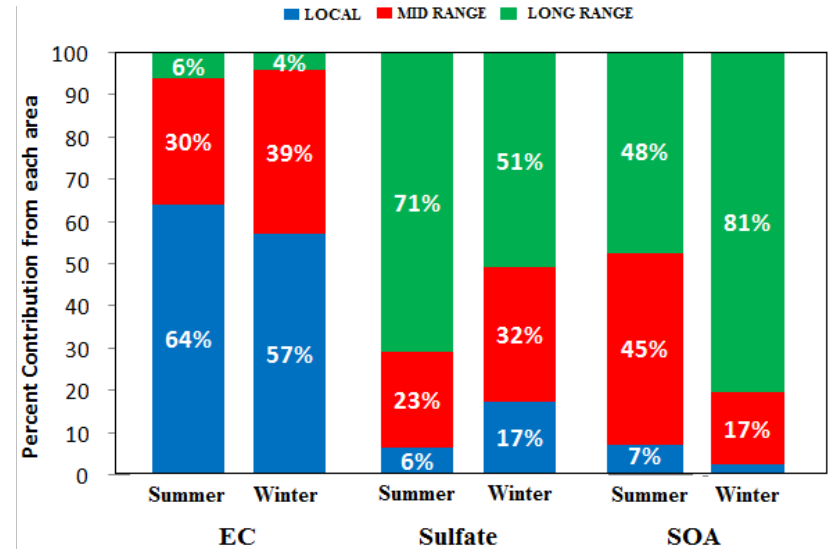

Fig. 9. Comparison of the contributions of each source area for the summer and winter periods.

\section{Comparison of PSAT results and observation-based estimates}

Beekmann et al. (2014) performed a detailed analysis of measurement data collected inside and outside Paris, in order to determine the role of local and regional sources. They concluded that on an annual basis, $70 \%$ of total $\mathrm{PM}_{2.5}$ is transported into Paris from areas far away from it. PSAT estimated (as the average of two periods) that $80 \%$ is transported. Both the analysis of measurements and the PSAT simulations suggest that more than $80 \%$ of the sulfate is transported to Paris from other areas (Fig. 10). The two approaches are in excellent agreement during the winter, but PSAT analyzes a lower contribution of local emissions during the summer. The discrepancy is of the order of $0.2 \mu \mathrm{g} \mathrm{m}^{-3}$ and could be the result of underestimating the effect of local sources, as PMCAMx underpredicts the average sulfate in the center of the city by the same amount (Fountoukis et al., 2013) while it is not biased outside Paris. Also the local simulated contributions of OA are lower than those estimated by observations for both summer and winter. This underestimation of local sources (almost $0.2 \mu \mathrm{g} \mathrm{m}^{-3}$ for summer and winter) could be explained by the behavior of fresh POA. Both the measurement-based studies of Beekmann et al. (2014) and Freutel et al. (2013) found that almost $62 \%$ of the OA in the center of Paris was HOA (Primary Organic Aerosol) and cooking $\mathrm{OA}$ and $38 \%$ was oxygenated $\mathrm{OA}$. The discrepancy between the measurements and the model can be explained by the cooking emissions which have not been included in the PMCAMx inventory used in this study. Cooking was estimated by Beekmann et al. (2014) to be a significant local source in Paris. On the other hand the local simulated contributions of EC are higher than the measured especially during summer but the absolute discrepancies are of the order of $0.2 \mu \mathrm{g} \mathrm{m}^{-3}$ for both summer and winter.

Healy et al. (2013) also calculated the local and transported PM into the center of the Paris based on observations 
Table 1. Emission densities for each source area during the simulated summer and winter periods.

\begin{tabular}{|c|c|c|c|c|c|c|c|c|c|c|}
\hline & \multicolumn{2}{|c|}{$\begin{array}{c}\mathrm{EC} \\
\left(\mathrm{kg} \mathrm{km}^{-2}\right)\end{array}$} & \multicolumn{2}{|c|}{$\begin{array}{l}\text { Fresh POA } \\
\left(\mathrm{kg} \mathrm{km}^{-2}\right)\end{array}$} & \multicolumn{2}{|c|}{$\begin{array}{l}\text { Anthropogenic SOA } \\
\text { precursors }\left(\mathrm{kg} \mathrm{km}^{-2}\right)\end{array}$} & \multicolumn{2}{|c|}{$\begin{array}{c}\text { Biogenic SOA } \\
\text { precursors }\left(\mathrm{kg} \mathrm{km}^{-2}\right) \\
\end{array}$} & \multicolumn{2}{|c|}{$\begin{array}{c}\mathrm{SO}_{2} \\
\left(\mathrm{~kg} \mathrm{~km}^{-2}\right)\end{array}$} \\
\hline & Summer & Winter & Summer & Winter & Summer & Winter & Summer & Winter & Summer & Winter \\
\hline Local & 9.7 & 12.6 & 5.6 & 13.4 & 298.9 & 366.8 & 136.9 & 22.8 & 11.2 & 47.2 \\
\hline Mid-range & 5.7 & 7.9 & 6.9 & 10.2 & 133.7 & 123.8 & 309.3 & 24.3 & 26.2 & 36.1 \\
\hline Long range & 1.2 & 0.3 & 1.5 & 0.1 & 45.9 & 16.7 & 136.5 & 3.9 & 8.9 & 8.9 \\
\hline
\end{tabular}

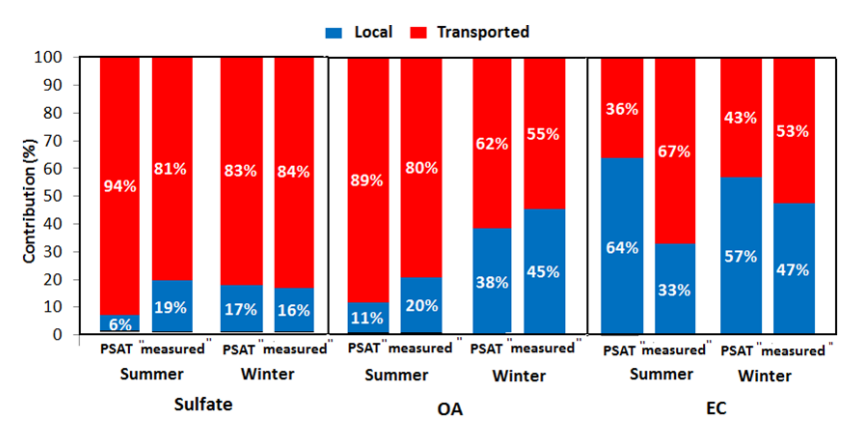

Fig. 10. Comparison of simulated and measured contributions of local and regional sources for EC, sulfate and OA for the summer and winter periods.

during January-February 2010. PSAT predicts that during the winter period the local contributions are $57 \%, 17 \%$ and $38 \%$ for EC, sulfate and OA, respectively, while Healy et al. (2013) estimated these contributions to be 59\%,16\% and $24 \%$, respectively. Generally the predictions of the model are in a good agreement with the estimates based on measurements and this agreement is encouraging for both approaches.

\section{Comparison with other source-receptor analysis methods}

We also used PMCAMx-2008 (Fountoukis et al., 2011) to analyze the contributions of each selected source area to PM in Paris by zeroing out all the emissions (particles and gases) from different areas around Paris. These areas were selected to be the same with those defined in PSAT simulations. Two additional simulations were performed: one zeroing out the emissions of Paris (local emissions) and one zeroing emissions originating from areas that are outside of Paris but less than $500 \mathrm{~km}$ away from it. An additional simulation taking into account only the boundary conditions was performed in order to calculate the impacts of the boundary conditions on the concentration levels considering them as long range transport. The results of these were combined with those of the base case simulation. Figure 11 compares the results of the two methods (brute force and PSAT) during summer. There is good agreement between the two methods for both the primary and secondary components. This agreement of

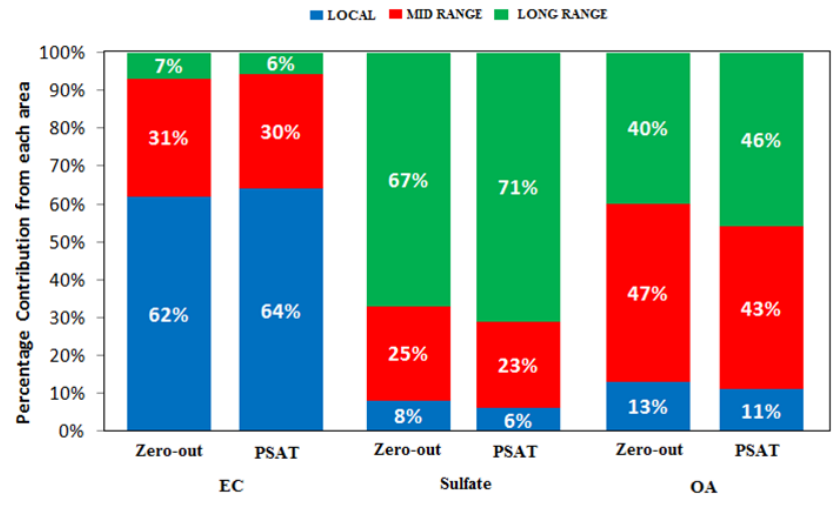

Fig. 11. Simulated contributions of emissions from different source areas to EC, sulfate and OA concentrations during the summer in Paris for the zero-out approach and PSAT.

the contributions of secondary species is unexpectedly good given the nonlinearity of the system. However, PSAT requires 5 times less CPU time than the brute force method for these calculations and is more accurate.

\section{Conclusions}

In this study we implemented the PM source apportionment algorithm PSAT together with the volatility basis set framework for OA, in the megacity of Paris. This new version of PSAT is used to quantify the contributions from selected source areas to Paris fine PM mass concentrations for two periods, a summer and a winter month. The contribution of local sources (within $50 \mathrm{~km}$ from the center of the Paris) was found to be around $60 \%$ for EC during both periods. On the other hand the concentrations of secondary PM components like sulfate and SOA were dominated by long range and midrange transport, respectively. Long range transport was responsible for $71 \%$ of the sulfate during summer and $51 \%$ during winter. For SOA during summer the contributions of mid- and long range transport were similar (45\% and $48 \%$ respectively) while during winter long range transport dominates $(81 \%)$. During more polluted days the contribution of regional sources was simulated to increase slightly for all PM species.

PSAT-simulated local contributions of EC are higher than those estimated by the observation-based method especially 
during summer (with local simulated being $64 \%$ and observation based $33 \%$ ) either indicating that the local emission sources of EC in Paris have been overestimated or that the observation-based approach is biased low. On the other hand the comparison between the simulated contributions and those estimated based on measurements for sulfate is encouraging with simulated transported contribution being $94 \%$ during summer and $83 \%$ during winter and the measured $81 \%$ and $84 \%$, respectively. Also OA mass was found to be transported into Paris from regional sources, on average $89 \%$ during summer and $62 \%$ during winter and these results are relatively consistent with the observation-based estimated values ( $80 \%$ and $55 \%$, respectively). The dominance of the contribution of regional sources for secondary species like sulfate and SOA for the center of Paris is the result of the time required to convert precursors to PM species. The contribution of long range transport was found to increase as the particles were further oxidized. PSAT results were found to be in good agreement with those of different "annihilation" scenarios, but PSAT is more computationally efficient.

Acknowledgements. This work was funded by the MEGAPOLI project which is financially supported by the European Community's Framework Program FP7 under grant agreement 212520 and the ATMOPACS project (grant agreement 267099).

Edited by: A. Baklanov

\section{References}

Baklanov, A., Lawrence, M., Pandis, S., Mahura, A., Finardi, S., Moussiopoulos, N., Beekmann, M., Laj, P., Gomes, L., Jaffrezo, J.-L., Borbon, A., Coll, I., Gros, V., Sciare, J., Kukkonen, J., Galmarini, S., Giorgi, F., Grimmond, S., Esau, I., Stohl, A., Denby, B., Wagner, T., Butler, T., Baltensperger, U., Builtjes, P., van den Hout, D., van der Gon, H. D., Collins, B., Schluenzen, H., Kulmala, M., Zilitinkevich, S., Sokhi, R., Friedrich, R., Theloke, J., Kummer, U., Jalkinen, L., Halenka, T., Wiedensholer, A., Pyle, J., and Rossow, W. B.: MEGAPOLI: concept of multiscale modelling of megacity impact on air quality and climate, Adv. Sci. Res., 4, 115-120, doi:10.5194/asr-4-115-2010, 2010.

Beekmann, M., Prévôt, A. S. H., Drewnick, F., Sciare, J., Pandis, S. N., Denier van der Gon, H. A. C., Crippa, M., Freutel, F., Poulain, L., Ghersi, V., Rodriguez, E., Beirle, S., Zotter, P.,von der Weiden-Reinmüller, S.-L., Bressi, M., Fountoukis, C., Petetin, H., Szidat, S., Schneider, J., Rosso, A., El Haddad, I., Megaritis, A., Zhang, Q. J., Slowik, J. G., Moukhtar, S., Kolmonen, P., Stohl, A., Eckhardt, S., Borbon, A., Gros, V., Marchand, N., Jaffrezo, J. L., Schwarzenboeck, A., Colomb, A., Wiedensohler, A., Borrmann, S., Lawrence, M., Baklanov, A., and Baltensperger, U.: Regional emissions control fine particulate matter levels in the Paris megacity, Atmos. Chem. Phys., in review, 2014.

Burtraw, D., Krupnick, A., Mansur, E., Austin, D., and Farrell, D.: Costs and benefits of reducing air pollutants related to acid rain, Contemp. Econ. Policy, 16, 379-400, doi:10.1111/j.14657287.1998.tb00527.x, 2007.

Cabada, J. C., Pandis, S. N., Subramanian, R., Robinson, A. L., Polidori, A., and Turpin, B.: Estimating the secondary organic aerosol contribution to $\mathrm{PM}_{2.5}$ using the EC tracer method, Aerosol Sci. Tech., 38, 140-155, 2004.

Chin, Mian, Diehl, T., Ginoux, P., and Malm, W.: Intercontinental transport of pollution and dust aerosols: implications for regional air quality, Atmos. Chem. Phys., 7, 5501-5517, doi:10.5194/acp7-5501-2007, 2007.

Couvidat, F., Kim, Y., Sartelet, K., Seigneur, C., Marchand, N., and Sciare, J.: Modeling secondary organic aerosol in an urban area: application to Paris, France, Atmos. Chem. Phys., 13, 983-996, doi:10.5194/acp-13-983-2013, 2013.

Crippa, M., DeCarlo, P. F., Slowik, J. G., Mohr, C., Heringa, M. F., Chirico, R., Poulain, L., Freutel, F., Sciare, J., Cozic, J., Di Marco, C. F., Elsasser, M., Nicolas, J. B., Marchand, N., Abidi, E., Wiedensohler, A., Drewnick, F., Schneider, J., Borrmann, S., Nemitz, E., Zimmermann, R., Jaffrezo, J.-L., Prévôt, A. S. H., and Baltensperger, U.: Wintertime aerosol chemical composition and source apportionment of the organic fraction in the metropolitan area of Paris, Atmos. Chem. Phys., 13, 961-981, doi:10.5194/acp-13-961-2013, 2013.

Dockery, D. W., Pope, C. A., Xu, X., Spengler, J. D., Ware, J. H., Fay, M. E., Ferris, B. G., and Speizer, F. E.: An association between air pollution and mortality in six US cities, New Engl. J. Med., 329, 1753-1759, 1993.

Donahue, N. M., Robinson, A. L., Stanier, C. O., and Pandis, S. N.: Coupled partitioning, dilution, and chemical aging of semivolatile organics, Environ. Sci. Technol., 40, 2635-2643, 2006.

Dunker, A. M.: Efficient calculation of sensitivity coefficients for complex atmospheric models, Atmos. Environ., 15, 1155-1161, 1981.

Dunker, A. M., Yarwood, G., Ortmann, J. P., and Wilson, G. M.: The decoupled direct method for sensitivity analysis in a threedimensional air quality model-implementation, accuracy and efficiency, Environ. Sci. Technol., 36, 2965-2976, 2002.

Fountoukis, C., Racherla, P. N., Denier van der Gon, H. A. C., Polymeneas, P., Charalampidis, P. E., Pilinis, C., Wiedensohler, A., Dall'Osto, M., O’Dowd, C., and Pandis, S. N.: Evaluation of a three-dimensional chemical transport model (PMCAMx) in the European domain during the EUCAARI May 2008 campaign, Atmos. Chem. Phys., 11, 10331-10347, doi:10.5194/acp11-10331-2011, 2011.

Fountoukis, C., Koraj, Dh., Denier van der Gon, H. A. C., Charalampidis, P. E., Pilinis, C., and Pandis, S. N.: Impact of grid resolution on the predicted fine PM by a regional 3-D chemical transport model, Atmos. Environ., 68, 24-32, 2013.

Freutel, F., Schneider, J., Drewnick, F., von der Weiden-Reinmüller, S.-L., Crippa, M., Prévôt, A. S. H., Baltensperger, U., Poulain, L., Wiedensohler, A., Sciare, J., Sarda-Estève, R., Burkhart, J. F., Eckhardt, S., Stohl, A., Gros, V., Colomb, A., Michoud, V., Doussin, J. F., Borbon, A., Haeffelin, M., Morille, Y., Beekmann, M., and Borrmann, S.: Aerosol particle measurements at three stationary sites in the megacity of Paris during summer 2009: meteorology and air mass origin dominate aerosol particle composition and size distribution, Atmos. Chem. Phys., 13, 933-959, doi:10.5194/acp-13-933-2013, 2013. 
Healy, R. M., Sciare, J., Poulain, L., Crippa, M., Wiedensohler, A., Prévôt, A. S. H., Baltensperger, U., Sarda-Estève, R., McGuire, M. L., Jeong, C.-H., McGillicuddy, E., O’Connor, I. P., Sodeau, J. R., Evans, G. J., and Wenger, J. C.: Quantitative determination of carbonaceous particle mixing state in Paris using single-particle mass spectrometer and aerosol mass spectrometer measurements, Atmos. Chem. Phys., 13, 9479-9496, doi:10.5194/acp13-9479-2013, 2013.

Klemm, R. J., Mason, R. M., Heilig, C. M., Neas, L. M., and Dockery, D. W.: Is daily mortality associated specifically with fine particles? Data reconstruction and replication analysis, J. Air Waste Manage., 50, 1215-1222, 2000.

Knipping, E. M., Kumar, N., Pun, B. K., Seigneur, C., Wu, S. Y., and Schichtel, B.A.: Modeling regional haze during the BRAVO study using CMAQ-MADRID: 2.Source region attribution of particulate sulfate compounds, J. Geophys. Res., 111, D06303, doi:10.1029/2004JD005609, 2006.

Koo, B. Y., Wilson, G. M., Morris, R. E., Dunker, A. M., and Yarwood, G.: Comparison of source apportionment and sensitivity analysis in a particulate matter air quality model, Environ. Sci. Technol., 43, 6669-6675, 2009.

Kunzli, N., Kaiser, R., Medina, S., Studnicka, M., Chanel, O., Filiger, P., Herry, M., Horak, F., Puybonnieux-Texier, V., Quenel, P., Schneider, J., Seethaler, R., Vergnaud, J. C., and Sommer, H.: Public-health impact of outdoor and traffic-related air pollution, Lancet, 356, 795-801, 2000.

Lane, T. E., Donahue, N. M., and Pandis, S. N: Simulating secondary organic aerosol formation using the volatility basis-set approach in a chemical transport model, Atmos. Environ., 42, 7439-7451, 2008.

Murphy, B. N. and Pandis, S. N.: Exploring summertime organic aerosol formation in the eastern United States using a regionalscale budget approach and ambient measurements, J. Geophys. Res., 115, D24216, doi:10.1029/2010JD014418, 2010.

Odum, J. R., Hoffman, T., Bowman, F., Collins, D., Flagan, R. C., and Seinfeld, J. H.: Gas/particle partitioning and secondary organic aerosol yields, Environ. Sci. Technol., 30, 2580-2585, 1996.

Park, R. J., Jacob, D. J., Chin, M., and Martin, R. V: Sources of carbonaceous aerosols over the United States and implications for natural visibility, J. Geophys. Res., 108, 4355, doi:10.1029/2002JD003190, 2003.

Pope, C. A., Burnett, R. T., Thun, M. J., Calle, E. E., Krewski, D., Ito, K., and Thurston, G. D: Lung cancer, cardiopulmonary mortality, and long-term exposure to fine particulate air pollution, Jama-J. Am. Med. Assoc., 287, 1132-1141, 2002.

Pun, B. K., Seigneur, C., and Lohman, K.: Modeling secondary organic aerosol formation via multiphase partitioning with molecular data, Environ. Sci. Technol., 40, 4722-4731, 2006.

Robinson, A. L., Donahue, N. M., Shrivastava, M. K., Wietkamp, E. A., Sage, A. M., Grieshop, A. P., Lane, T. E., Pierce, J. R., and Pandis, S. N.: Rethinking organic aerosols: Semivolatile emissions and photochemical aging, Science, 315, 1259, doi:10.1126/science.1133061, 2007.

Royer, P., Chazette, P., Sartelet, K., Zhang, Q. J., Beekmann, M., and Raut, J.-C.: Comparison of lidar-derived $\mathrm{PM}_{10}$ with regional modeling and ground-based observations in the frame of MEGAPOLI experiment, Atmos. Chem. Phys., 11, 1070510726, doi:10.5194/acp-11-10705-2011, 2011.
Schwartz, J.: Air pollution and hospital admissions for respiratory disease, Epidemiology, 7, 20-28, 1996.

Sciare, J., d'Argouges, O., Zhang, Q. J., Sarda-Estève, R., Gaimoz, C., Gros, V., Beekmann, M., and Sanchez, O.: Comparison between simulated and observed chemical composition of fine aerosols in Paris (France) during springtime: contribution of regional versus continental emissions, Atmos. Chem. Phys., 10, 11987-12004, doi:10.5194/acp-10-11987-2010, 2010.

Seinfeld, J. H. and Pandis, S. N: Atmospheric Chemistry and Physics: From Air Pollution to Global Change, Second Edn., J. Wiley and Sons, New York, 2006.

Shrivastava, M. K., Lane, T. E., Donahue, N. M., Pandis, S. N., and Robinson, A. L.: Effects of gas-particle partitioning and aging of primary emissions on urban and regional organic aerosol concentrations, J. Geophys. Res., 113, D18301, doi:10.1029/2007JD009735, 2008.

Stanier, C. O., Donahue, N. M., and Pandis, S. N: Parameterization of secondary organic aerosol mass fraction from smog chamber data, Atmos. Environ., 42, 2276-2299, 2008.

Strader, R., Lurmann, F., and Pandis, S. N.: Evaluation of secondary organic aerosol formation in winter, Atmos. Environ., 33, 48494863, 1999.

Turpin, B. J. and Huntzicker, J. J.: Identification of secondary organic aerosol episodes and quantification of primary and secondary organic aerosol concentrations during SCAQS, Atmos. Environ., 29, 3527-3544, 1995.

Wagstrom, K. M. and Pandis, S. N.: Source receptor relationships for fine particulate matter concentrations in the Eastern United States, Atmos. Environ., 45, 347-356, 2011 a.

Wagstrom, K. M. and Pandis, S. N.: Contribution of long range transport to local fine particulate matter concerns, Atmos. Environ., 45, 2730-2735, 2011b.

Wagstrom, K. M., Pandis, S. N., Yarwood, G., Wilson, G. M., and Morris, R. E.: Development and application of a computationally efficient particulate matter apportionment algorithm in a three-dimensional chemical transport model, Atmos. Environ., 42, 5650-5659, 2008.

Ying, Q. and Kleeman, M. J.: Source contributions to the regional distribution of secondary particulate matter in California, Atmos. Environ., 40, 736-752, 2006.

Ying, Q. and Kleeman, M.: Regional contributions to airborne particulate matter in central California during a severe pollution episode, Atmos. Environ., 43, 1218-1228, 2009.

Zhang, Q. J., Beekmann, M., Drewnick, F., Freutel, F., Schneider, J., Crippa, M., Prevot, A. S. H., Baltensperger, U., Poulain, L., Wiedensohler, A., Sciare, J., Gros, V., Borbon, A., Colomb, A., Michoud, V., Doussin, J.-F., Denier van der Gon, H. A. C., Haeffelin, M., Dupont, J.-C., Siour, G., Petetin, H., Bessagnet, B., Pandis, S. N., Hodzic, A., Sanchez, O., Honoré, C., and Perrussel, O.: Formation of organic aerosol in the Paris region during the MEGAPOLI summer campaign: evaluation of the volatilitybasis-set approach within the CHIMERE model, Atmos. Chem. Phys., 13, 5767-5790, doi:10.5194/acp-13-5767-2013, 2013. 